ISSN : 2550-0198

\title{
PROGRAM BENGKEL DAN PELATIHAN TRAINING OTOMOTIF DI KELURAHAN LABUHBARU BARAT KECAMATAN PAYUNG SEKAKI PEKANBARU
}

\author{
Jusnita*, Indra Hasan, Muhammad Ridha Fauz, Denur, Yuhelson, Japri \\ Program Studi Mesin Otomotif, Fakultas Teknik \\ *Email: jusnita@umri.ac.id
}

\begin{abstract}
Abstrak
Kebutuhan service bagi sepeda motor menjadi kebutuhan rutin yang harus dilakukan oleh penggunanya. Tujuan dari kegiatan ini adalah memberikan pelatihan program bengkel dan training mekanik otomotif dan menumbuh kembangkan jiwa kewirausahaan, membantu program pemerintah dalam mengatasi pengangguran. Metode yang digunakan adalah ceramah, Tanya jawab, diskusi, demonstrasi dan latihan praktek. Manfaat pengbdian ini adalah; Peserta pelatihan mendapatkan pengetahuan dan keterampilan mekanik otmotif, Dosen dapat melaksanakan salah satu tri darma Perguruan Tinggi, untuk pemerintah setempat terbentuknya calon tenaga kerja yang berkualitas. Kegiatan ini diadakan di Kelurahan Labuhbaru Barat Kecamatan Payung Sekaki, diikuti oleh 15 orang peserta, 1 orang tamatan SD, 7 orang tamatan SMP dan 7 orang tamatan SLTA. Kegiatan ini diawali dengan mengumpulkan peserta di aula Kelurahan Labuhbaru Barat sebagai tempat pelatihan. Hasil kegiatan pengabdian masyarakat secara garis besar mencakup beberapa komponen sebagai berikut; 1). Keberhasilan target jumlah peserta pelatihan. 2) Ketercapaian tujuan pelatihan 3)Ketercapaian target materi yang telah direncanakan 4). Kemampuan peserta dalam penguasaan materi. Target peserta pelatihan seperti direncanakan sebelumnya 10 orang. Dalam pelaksanaannya, kegiatan ini diikuti oleh 15 orang peserta. Dengan demikian dapat dikatakan bahwa target peserta tercapai $100 \%$. Angka tersebut menunjukkan bahwa kegiatan pengabdian masyarakat dilihat dari jumlah peserta yang mengikuti dapat dikatakan berhasil/ sukses.
\end{abstract}

Kata kunci : Pelatihan, Bengkel, Training, Otomotif, Kewirausahan

\section{PENDAHULUAN}

Makin hari penambahan populasi kendaraan bermotor di Riau, khususnya di daerah kota Pekanbaru. Peningkatan penjualan sepeda motor ini menunjukkan indikasi daya beli masyarakat semakin membaik. Bahkan hampir setiap orang punya dan membutuhkan sepeda motor. Kepadatan aktivitas di jalan menuntut kenyamanan untuk itu kendaraan yang dipakai harus selalu dalam keadaan baik. Agar kendaraan selalu dalam keadaan baik maka diperlukan perawatan dan service berkala bahkan diperlukan juga perbaikan-perbaikan bagian yang rusak, untuk itu sangat dibutuhkan jasa bengkel motor.

Kondisi seperti inilah yang harus dimanfaatkan sebagai peluang usaha. Usaha bengkel motor memang menjanjikan, mengingat pengguna sepeda motor semakin banyak jumlahnya. Hal ini terbukti dari meningkatnya produksi sepeda motor pertahun. Kebutuhan service bagi sepeda motor menjadi kebutuhan 
ISSN : 2550-0198

rutin yang harus dilakukan oleh penggunanya. Apalagi didaerah Labuhbaru Barat yang notabennya adalah pemukiman penduduk. Daerah Labuhbaru Barat ini terdapat beberapa perumahan yang cukup padat penduduknya, sebagian besar warga disana menggunakan motor sebagai alat transportasi sehingga frekuensi perbaikan dan service motorpun tinggi.

\section{METODE PENGABDIAN}

Metode yang digunakan dalam pelatihan program bengkel dan training otomotif adalah Metode ceramah dan tanya jawab.Metode ini untuk menyajikan teori secara umum. Teori yang disampaikan adalah mekanik otomotif dan keselamatan kerja. Penyajian materi pada metode ini menggunakan alat peraga langsung.

Metode Resitasi Dan Diskusi, Setelah tim pelaksana selesai menyajikan materi, tugas diberikan kepada peserta dalam bentuk modul pelatihan. Semua peserta membaca masing-masing modul yang telah disiapkan oleh tim dan modul telah dilengkapi dengan petunjuk dan gambar kerja.

Metode demonstrasi merupakan sistem penyajian sub kerja pelayanan mekanik otomotif dengan teknis memperagakan kepada peserta. Sub kerja pelayanan sepeda motor terdiri dari Overhaul Engine, memperagakan suatu tindakan mencari gangguan kerusakan total pada mesin disaat mesin dikatagorikan rusak parah dan service berkala dan perawatan,

Memperagakan suatu tindakan perbaikan yang dilakukan secara berkala dan intensif yang disesuaikan standar operasional produk (S.O.P)

\section{HASIL DAN PEMBAHASAN}

Hasil yang dicapai melalui kegiatan pengabdian ini dituangkan dalam bentuk hasil kegiatan pada setiap tahap pelaksanaan sebagai berikut :

\section{Hasil Kegiatan}

\section{Perencanaan}

Kegiatan-kegiatan yang dilakukan pada tahap perencanaan adalah Sosialisasi Program Kemitraan Masyarakat, Sosialisasi dilakukan pada bulan maret 2017 dalam bentuk rapat koordinasi dengan Kelurahan berkenaan dengan program yang dilaksanakan. Kegiatan sosialisasi dilakukan oleh ketua dan tim pelaksana.

Penyusunan Program Pelatihan Berdasarkan hasil identifikasi maka hasil dari analisa permasahan yang ada sesuai dengan kebutuhan dan potensi daerah setempat. maka selanjutnya disusun program pelatihan. Pelaksaanaan pelatihan dilakukan selama 1 hari tatap muka dengan jumlah maksimal 15 orang pemuda yang ada di Kecamatan Payung Sekaki Pekanbaru. Pelatihan yang diberikan berupa teori dari program bengkel dan training otomotif serta mengimplementasikannya dalam kegiatan kewirausahaan.

\section{Pelaksanaan Tindakan}

Tidakan dalam kegiatan ini berupa implementasi program. kegiatankegiatan yang dilakukan dalam implementasi programseba gai berikut: a) Mengmpulkan seluruh 
peserta pelatihan dengan memberikan arahan dan aturan-aturan dalam mengikuti kegiatan ini, kegiatan ini dilaksanakan pada bulan Maret 2017.

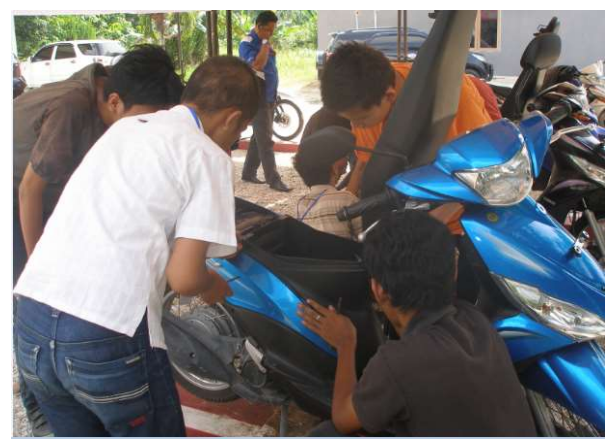

Gambar 1. Training Otomotif

Meningkatkan pengetahuaan dan keterampilan pemuda dilingkungan Kelurahan Labuhbaru Barat Kecamatan Payung Sekaki, kegiatan ini dilakukan melalui pemberian pelatihan program bengkel dan training otomotif yang sesuai dengan Standar Operasional Prosedur (SOP). Pemberian materi pelatihan teori di bimbingan oleh tim pelaksana (dosen Program Studi Mesin Otomotif Fakultas Teknik UMRI) dengan memberi modul kepada peserta pelatihan.

\section{Pelatihan Manajemen Bengkel}

Manajemen adalah proses perencanaan, pengorganisasian, kepemimpinan, dan pengendalian/ pengontrolan upaya anggota organisasi dan penggunaan seluruh sumber daya organisasi demi tercapainya tujuan yang ditetapkan. Manajemen merupakan suatu proses perencanaan pengorganisasian, kepemimpinan dan pengendalian. Masing-masing sub-sub proses di dalam manajemen sangat komplek.

Bengkel adalah tempat yang digunakan untuk merawat dan memperbaiki mesin-mesin, maupun peralatan. Fungsi bengkel adalah sebagai tempat perawatan, perbaikan, dan penggantian komponen sistem sebuah mesin maupun peralatan lainnya.

Manajemen bengkel adalah suatu proses perencanaan, pengorganisasian, kepemimpinan dan pengendalian suatu tempat merawat dan memperbaiki mesin ataupun peralatan lain. Bengkel pada umumnya terbagi 2 bagian yaitu secara umum berfungsi sebagai tempat service, repair, dan maintenance atau (Perawatan, Perbaikan, dan Pemeliharaan) yang konotasi artinya dapat dijelaskan sebagai Perbaikan, yaitu mengganti bagian yg aus/rusak agar tidak terjadi kesalahan,

Gambar 2. Lurah Labuhbaru Barat

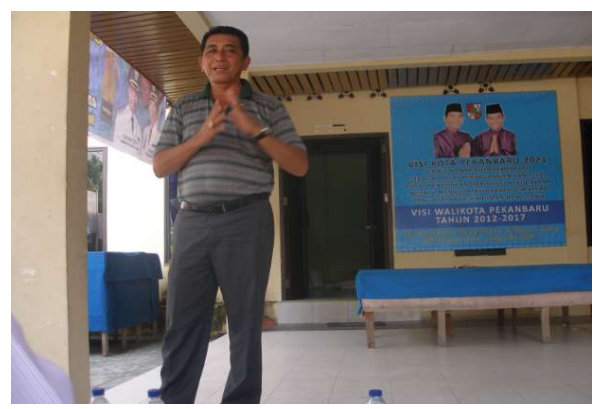

Perawatan, yaitu agar kondisi tetap terjaga dan umur pemakaian menjadi awet dan pemeliharaan, yaitu agar dapat berproduksi secara effisien dan mampu berkembang.

Pelatihan manajemen bengkel dilaksanakan selama 3 kali pertemuan. Pelatihan ini bertujuan untuk 1) Meningkatkan pengetahuan dan jiwa kewirausahaan perbengkelan otomotif 2) Meningkat kemampuan pembukuaan usaha 3) Meningkatkan pengetahuan dan 
ISSN : 2550-0198

kemampuan manajemen bengkel terumata manajemen pemasaran dalam rangka meningkatkan pendapatan usaha

Pelatihan manajemen bengkel yang dilaksanakan berisi antara lain adalah pelatihan kewirausahan, pelatihan pembukuan dan manajemen pemasaran.

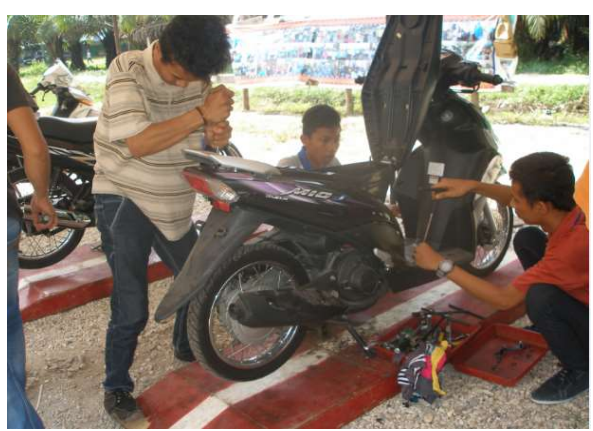

Gambar 3. Peserta Pelatihan Praktek Mekanik Sepeda Motor

Peserta pelatihan yang menjadi mitra dalam kegiatan pelatihan ini berpartisipasi dalam setiap kegiatan yang diselenggarakan. Disamping berpartisipasi sebagai peserta, mitra juga berperan dalam menyediakan tempat pelatihan, dan mensosialisasikan program kemitran masyarakat dan bekerjasama dengan tim dalam mengadakan konsumsi pelatihan. Sehingga partisipasi mitra sangat mendukung terhadap pelaksanan Program Kemitraan Masyarakat secara keseluruhan.

Pelaksanaan Program Kemitraan Masyarakat (PKM) mendapat respon positif dari peerta. Harapan dari tim pelaksana adalah diharap peserta pelatihan bisa membuka usaha sendiri ataupun berkelompok.

Hasil kegiatan program pengabdian masyarakat secara garis besar mencakup beberapa komponen diantaranya Keberhasilan target jumlah peserta pelatihan, ketercapaian tujuan pelatihan, ketercapaian target materi yang telah direncanakan, kemampuan peserta dalam penguasaan materi.

Target peserta pelatihan seperti direncanakan sebelumnya adalah maksimal 15 pemuda di Kelurahan Labuhbaru Barat Kecamatan Payung Sekaki. Dalam pelaksanaannya, kegiatan ini diikuti oleh 15 orang peserta.

Dengan demikian dapat dikatakan bahwa target peserta tercapai $100 \%$. Angka tersebut menunjukkan bahwa kegiatan program pengabdian dilihat dari Jumlah peserta yang mengikuti dapat dikatakan berhasil/ sukses.

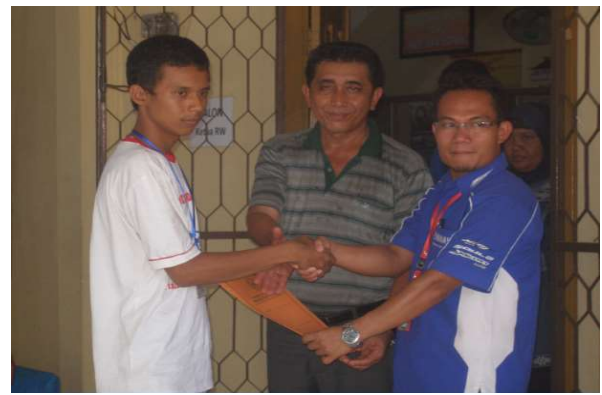

Gambar 4. Peserta Pelatihan Dengan Mitra

Ketercapaian tujuan penyuluhn program bengkel dan training otomotif secara umum sudah baik, namun keterbatasan waktu yang disediakan mengakibatkan tidak semua materi tentang program bengkel dan training penyuluhan otomotif dapat disampaikan secara detil. Namun dilihat dari hasil latihan para peserta yaitu kualitas media pembelajaran yang telah dihasilkan, maka dapat disimpulkan bahwa tujuan kegiatan ini dapat tercapai.

Ketercapaian target materi pada kegiatan pengabdian ini cukup baik, karena materi program bengkel dan training penyuluhan otomotif telah 
ISSN : 2550-0198

dapat disampaikan secara keseluruhan. Kemampuan peserta dilihat dari penguasaan materi masih kurang dikarenakan waktu yang singkat dalam penyampaian materi dan kemampuan para peserta yang berbeda-beda. Hal ini disebabkan jumlah materi yang banyak hanya disampaikan dalam waktu sehari sehingga tidak cukup waktu bagi para peserta untuk memahami dan mempraktekkan secara lengkap semua materi yang diberikan.

\section{KESIMPULAN}

Hasil yang dicapai melalui kegiatan program pengabdian masyarakat ini untuk pemuda di Kelurahan Labuhbaru Barat adalah 1) Menambah ilmu pengetahuan dan keterampilan tentang mekanik otomotif dengan pendekatan IPTEK terapan, mengalami peningkatan dari kategori kurang menjadi baik. 2) Rata-rata kemampuan peserta pelatihan menggunakan media pembelajaran mekanik otomotif yang telah dikembangkan sehingga berkualitas baik. 3) Terbukanya peluang-peluang usaha bengkel untuk pemuda di Kelurahan Labuhbaru Barat Kecamatan Payung Sekaki, 4) Dapat membantu pemerintah dalam mengatasi penganguran

\section{UCAPAN TERIMAKASIH}

Ucapan terima kasih atas pelaksanaan kegiatan pengabdian masyarakat kepada :

1. Rektor Universitas Muhammadiyah Riau yang telah menfasilitasi kegiatan pengabdian masyarakat ini.

2. Ketua LPPM UMRI yang telah mengagendakan kegiatan pengabdian masyarakat di lingkunan dosen UMRI

3. Dekan Fakultas Teknik UMRI yang telah memberi dukungan atas pelaksaan pengabdian ini.

4. Ketua Program Studi Mesin Otomotif yang telah memotifasi kegiatan pengabdian ini.

5. Semua dosen dan mahasiswa Program Studi Mesin Otomotif yang terlibat dalam agenda pengabdian masyarakat ini.

\section{DAFTAR PUSTAKA}

[1] Badan Pusat Statistik Kota Pekanbaru, (2010). Kecamatan Payung Sekaki Dalam Angka.http://www.riau24.com

[2] Badan Pusat Statistik Kota Pekanbaru, (2014). Kecamatan Payung Sekaki Dalam Angka.http://www.riau24.com

[3] Buku panduan reparasi Honda beat, technical service divison TSR10 PR 002 82KYTHO, BI.MAL.A 5000.2010.08.10

[4] YAMAHA MOTOR CO.LTD Service Advision, Basic Mechanic Training (BMT) 90894-00108, Otomotifnet.com

[5] Nugroho Beni Satriya, Sriyanto Joko, 2007, Aplikasi Teknologi Injeksi Bahan Bakar Elektronik (EFI) Untuk Mengurangi Emisi Gas Buang Sepeda Motor

[6] Suzuki Indonenesia.,(2012)., Mesin Hemat Bahan Bakar dengan Service Berkala., Book Manual Service., vol 2., hal 2324

[7] UNEP.,(2008)., Pedoman Efisiensi Energi untuk Industri di Asia- www. Energy efficiency asia.org. 


\section{ISSN : 2550-0198}

[8] Astra Motor,2012, Buku Pedoman Reparasi Honda Baet. Jakarta : PT.Astra Motor

[9] Urip, sudirman, 2011. Bikin irit speda motor matik, Bandung: Penerbit Tri Niti Masa

[10] Soedarmo Hartoto, 2008, Marawat dan 